\title{
Colorization - The Saga of Legend Films
}

\author{
By Ron Holloway \\ Spring 2007 Issue of KINEMA
}

\section{COLORIZATION - WHY NOT? THE SAGA OF LEGEND FILMS}

Colorization is as old as the movies. In fact, it's even older. Although some historians are want to trace the theory of colour photography as far back as 1785, the first patent for colour film was registered sometime in the late 1800s. This was during the era of Georges Méliès, whose famed hand-tinted trick films delighted audiences as early as 1894. Edwin S. Porter borrowed the tinted technique to enhance the gunshot blast at the end of The Great Train Robbery (1904). Later, D. W. Griffith had gun explosions tinted in battle scenes of The Birth of a Nation (1915). And Sergei Eisenstein made sure that in the first prints of Battleship Potemkin (1925) a tinted red flag was raised to glorify the revolution.

The first commercially successful colour system to hit the market was Kinemacolor, patented in 1906 by British film pioneers George Albert Smith and Charles Urban. After experimenting with their system on short films, they produced the first lengthy colour film, The Durbar at Delhi (1911), a colourful record of the Indian celebration of the coronation of King George V. To enjoy this highly profitable movie event that toured the world, special projection equipment was required, to say nothing of a demanding persistence-ofvision ordeal on the part of the audience to blend the colours together in the visual experience. By 1913, Kinemacolor was on its way out, its studio on Sunset and Hollywood in Los Angeles taken over by Griffith for Biograph melodramas and thrillers.

Throughout the 1920s and 1930s various methods of tinting, toning, and colouring film stock were experimented with, the most successful of which proved to be Technicolor, used to great effect in Douglas Fairbanks's The Black Pirate (1926), directed by Albert Parker. Since the production used a two-strip colour system, it demanded a trained projectionist to keep the print from warping or scratching - enough trouble to force the Fairbanks Studio to release a black-and-white print as well. It wasn't until the MGM release of producer David O. Selznick's Gone With the Wind (1939), arguably the highest grossing film of all time, that a more simplified Technicolor process was hailed as the cinema of the future. Today, films in colour are the norm rather than the exception.

On the other hand, there are many who prefer their cinema packaged as luminous black-and-white 35mm prints manufactured on a silver nitrate base. Although highly inflammable and prone to deteriorate, these nitrate prints were the rule during the silent era and continued to be manufactured well into the 1950s. Once, during a visit to the Cinémathèque Française, I had the good fortune to view original nitrate prints of Mary Pickford films, and the experience was enough to take your breath away. Indeed, the subsequent shift from silver nitrate to safety acetate prints must be deemed a definite loss for all concerned. So it is mystery to me why some critics continue to claim that black-and-white prints should never be colorized for commercial use, particularly since most of those critical voices have probably never experienced the pleasure of viewing silver nitrate prints - namely, black-and-white cinema in its purest form.

Along came Ted Turner, and the world of colorization was turned upside down. In 1986, TNT (Turner Network Television) purchased the MGM/UA library of 3,300 films, to which Turner added films produced by Warner Bros. and RKO. Programming vintage Hollywood classics on his chain of cable stations proved to be a windfall, for TV audiences craved for just this opportunity. The rub came when Turner hired American Film Technologies (AFT), a San Diego company founded by Barry Sandrew, to colorize black-and-white Hollywood classics. The loudest protests were heard from film professionals - producers, directors, actors, cinematographers - who felt that a cultural heritage was being vandalized on the grounds that colorization was completely contrary to artistic vision and creative intent.

To some extent, these protests were valid. In retrospect, the AFT colorization process, as it existed twenty years ago, was visually flat - that is, the colour process lacked both natural and realistic tones. Thus, it was not surprising that over the years the novelty would eventually wear off, so much so that audiences began to disapprove of indiscriminate colorization of Hollywood classics without enhancing their thematic content. 
One reason, said Barry Sandrew, was "the lack of proper colour stock back then, which made it hard to do backgrounds and make films look the way I wanted them to."

Enter Legend Films. Founded by Barry Sandrew in 2001, his new San Diego company benefited from fifteen years of advanced colorization technology. Its aim also differs from the policies of the previous AFT colorization process. The company first restores classic black-and-white films before colorizing them for DVD, HDTV, and theatrical release, thus allowing the viewer to choose on a single DVD disc between the original black-and-white film and a new digitalized colorized version. "The colorization technology has now come of age," says Barry Sandrew. "We can reproduce high-definition digital images with colours and resolutions never before possible."

The first of the prior colorization doubters to be convinced of the new process was Shirley Temple Black. When she viewed a high-definition colorized version of her Heidi (1937), she felt that "the film had a totally fresh and new look." Currently, all the films in her personal library, including the Baby Burlesk (1933) series and the Shirley Temple Storybook Collection (1958), are available via Legend Films. Another convert to colorization is special effects filmmaker Ray Harryhausen, whose inventive stop-motion animation had powered Ernest B. Schoedsack's Mighty Joe Young (1949) to cult status among entertainment spectacles. "I wanted to shoot many of my early films in colour," said Harryhausen, "but the studios wouldn't pay for it. With Barry's colour technology people will be able to see these films the way I had originally envisioned them."

Legend Films is best known among film buffs for its cult series. The "Off Colour Series" includes such offbeat classics as Louis J. Gasnier's Reefer Madness (1936), Edward D. Woods's Plan 9 from Outer Space (1959), Roger Corman's Little Shop of Horrors (1960), and George A. Romero's Night of the Living Dead (1968). Slapstick takes on a new dimension in the colorized versions of The Three Stooges shorts of the 1930s. And documentary fans can view colorized versions of Manny Nathan Hahn's Seabiscuit: The Lost Documentary (1939) and Alfred E. Green's The Jackie Robinson Story (1950).

Legend Films currently releases two films a month. Besides the twenty-five workers at the San Diego headquarters, the company employs an additional 200 at its colorization facility in Patna, India. Noting that the average feature film contains approximately 140,000 frames, each of these frames have to be dusted and cleaned before separately colorized to match as closely as possible the colour schemes in the original shoot. The entire process takes two weeks of design study, followed by four more weeks to apply the correct array of colours.

\section{On Colorization by Legend Films in Europe - Short Interview with Manya Lutz}

\section{Who are your clients?}

We have two different markets, offering both Legend Films' colorization and restoration services. On one hand, you have rights owners of black-and-white films, such as film producers or archives. As most of the black-and-white films were shot for reasons of economy, not art, these films when colorized could become more attractive to a younger audience. It also gives the clients a distinct chance in marketing special editions on DVD, including the colorized and restored version along with the black-and-white original. And on the other hand, you can use colorization in today's productions. Legend Films has worked, for example, on several scenes of the historical film The Aviator, directed by Martin Scorsese. As this film used black-and-white vintage footage, it was colorized to fit with newly shot material. By colorizing existing vintage footage, rather than recreating a vintage set and shooting anew, this process can save the producer significant production costs. The response to use colorization in advertising or music clips is very high as well. We are currently planning to test partial colorization in a clip with a renowned German DP-and-director team. The creative people we are talking to are very keen on working with colorization and creating a new look.

\section{How does the technical process work?}

First, the condition of the film negative or positive will be checked. Then a quality control or synch test and evaluation of image and sound on Telecine will be done. The sound will be backed by transferring the optical sound negative to Pro Tools system. If desired, the sound can be restored in a separate post production process. The picture will be transferred on $\mathrm{HD}$ or scanned in $2 \mathrm{~K}$ or $4 \mathrm{~K}$. Then the picture will 
be retouched. The play-out will be done on the desired format and be shipped to our head office in San Diego in the US The colour catalogue and the look will be developed in San Diego by Legend Films' Creative Director and Senior Designer. When approved by the client, this information along with the data will be sent to Legend Films' office in North India were the frames get colorized. Back in San Diego, the colorization gets polished and finalized and sent back to Europe.

The data containing the colorized picture will be transferred to the format desired along with the sound, restored or not. All video distribution formats - like HD, DVD, PAL, and NTSC - will be possible. And if the colorized material will be recorded to $35 \mathrm{~mm}$, then any particular format would be possible.

\section{Do you offer any cooperation with a post production facility?}

Yes, we do. In Europe, we cooperate with the well-known Munich based ARRI Group offering services on the quality check and the digital transfer of the original material to be colorized. However, we are also pleased to cooperate with the partner chosen by our client.

Thank you for the interview, and good luck at Legend Films München.

\section{Author Information}

Ron HOLLOWAY (1933-2009) was an American critic, film historian, filmmaker and correspondent who adopted Europe as his home in the early fifties and spent much of his life in Berlin. He was an expert on the study of German cinema and against all odds produced, with his wife Dorothea, the journal German Film, keeping us up-to-date with the work of directors, producers and writers and the showing of German films around the world.

In 2007, Ron Holloway and his wife were awarded the Berlinale Camera Award. Ron also received the Bundesverdienstkreuz (German Cross of Merit), Polish Rings, Cannes Gold Medaille, the American Cinema Foundation Award, the Diploma for Support of Russian Cinema and an honorary award from the German Film Critics' Association.

Ron was also a valued contributor to Kinema for the past fifteen years. 